\title{
Records of bats and rodents from Venezuela
}

\author{
by J. OCHOA G. ', H. CASTELLANOS ${ }^{2}$ and C. IBAÑEZ ${ }^{3}$
}

\author{
'Servicio Nacional de Fauna Silvestre (MARNR), \\ Apartado 184, Maracay-Aragua, Venezuela \\ ${ }^{2}$ CVG-TECMIN Ca., Edif. CVG (2nd Piso), \\ Ciudad Bolivar, Edo. Bolivar, Venezuela \\ ${ }^{3}$ Estación Biológica de Doñana, Apartado 1056, 41080 Sevilla, Spain
}

Summary. - Data on the occurrence in Venezuela of six bats and two rodents are presented, including the first records for the country of Nyctinomops macrotis and Oryzomys yunganus.

Résumé. - Informations sur la présence au Venezuela de six chauve-souris et de deux rongeurs, dont Nyctinomops macrotis et Oryzomys yunganus qui sont nouveaux pour ce pays.

\section{INTRODUCTION}

As result of recent investigations related to the inventory of the mammals from Venezuela, new data have been gathered on six bats and two rodents previously not recorded in the country, or whose distribution is known only from few specimens and localities. The material examined is deposited in the following venezuelan institutions : Estación Biológica de Rancho Grande (EBRG), Museo de Historia Natural La Salle (MHNLS), Museo de Biología de la Universidad Central de Venezuela (MBUCV), Colección de Vertebrados de la Universidad de los Andes (CVULA) and Museo del Instituto de Zoología Agrícola de la Universidad Central de Venezuela (MIZAUCV). Measurements are given in millimeters and correspond to adult specimens. Cranial measurements of bats do not include the incisors, excepting the condylobasal length of Pteronotus gymnonotus. Nomenclature of the molar components of Oryzomys yunganus follows Reig (1977).

\section{ACCOUNTS OF SPECIES}

\section{Diclidurus ingens Hernandez-Camacho}

Specimens examined (1). BoLIVAR : El Manteco, $300 \mathrm{~m}\left(7^{\circ} 31^{\prime} \mathrm{N}, 62^{\circ} 32^{\prime} \mathrm{W}\right), 1$ \% (EBRG).

Mammalia, $t .52, n^{\circ} 2,1988$. 
Ojasti and Linares (1971) and Handley (1976) reported this species in Venezuela from Sucre, Monagas and T.F. Amazonas. The new specimen extends the known range of this bat to the northern region of Bolivar. Some measurements are : forearm, 73.5 ; postorbital constriction, 5.3 ; palatal length, 10.4 ; maxillary toothrow, 9.2 ; breadth across upper molars, 9.3. Stomach contents were Lepidoptera, including eggs and remains of adults stages.

\section{Pteronotus gymnonotus (Natterer)}

Specimens examined (29). Bolivar : El Raudal, Caño El Cambur, $15 \mathrm{~km} \mathrm{SW} \mathrm{Maripa,}$ $100 \mathrm{~m}\left(7^{\circ} 25^{\prime} \mathrm{N}, 65^{\circ} 20^{\prime} \mathrm{W}\right), 4 \sigma^{\circ} 0^{\prime}, 3$ ९ ९ (MHNLS). San Luis, $230 \mathrm{~m}$ ( $\left.7^{\circ} 14^{\prime} \mathrm{N}, 62^{\circ} 45^{\prime} \mathrm{W}\right)$, $17 \sigma^{\circ} 0^{\circ}, 3$ ९ $९$ (EBRG). Quebrada El Garzón, $18 \mathrm{~km}$ S Río Parguaza, $100 \mathrm{~m}\left(6^{\circ} 24^{\prime} \mathrm{N}\right.$, $\left.67^{\circ} 02^{\prime} \mathrm{W}\right), 1 \sigma^{\circ}$ (MHNLS). Summit of El Abismo, near Icabarú, $960 \mathrm{~m}\left(4^{\circ} 20^{\prime} \mathrm{N}, 61^{\circ} 44^{\prime} \mathrm{W}\right)$, 1 o (MHNLS).

Previous records of this bat from Venezuela included only one specimen from the southern part of the country (Suapure, Bolivar), which corresponds to the holotype of $P$. suapurensis (Smith 1972). This last species was considered by Smith (1977) as synonymous of $P$. gymnonotus. Data here presented extend its known distribution to a wide region that embrases almost the whole Bolivar State.

TABLE 1. - Some external and cranial measurements of the specimens of Pteronotus gymnonotus examined for this paper. Data are : $\overline{\mathrm{X}}, \mathrm{N}$, (range) and SD.

\begin{tabular}{|c|c|c|}
\hline & Males & Females \\
\hline Forearm & $\begin{array}{c}51.0 \\
22(48.8-55.4) \\
1.34\end{array}$ & $\begin{array}{c}51.6 \\
6(50.1-53.2) \\
1.31\end{array}$ \\
\hline $\begin{array}{l}\text { Total length } \\
\text { of the skull }\end{array}$ & $\begin{array}{c}16.5 \\
14(16.1-16.8) \\
0.19\end{array}$ & $\begin{array}{c}16.4 \\
6(16.2-16.6) \\
0.20\end{array}$ \\
\hline $\begin{array}{l}\text { Condylobasal } \\
\text { length }\end{array}$ & $\begin{array}{c}16.6 \\
15(16.3-17.0) \\
0.22\end{array}$ & $\begin{array}{c}16.5 \\
4(16.4-16.5) \\
0.05\end{array}$ \\
\hline $\begin{array}{l}\text { Breadth of } \\
\text { braincase }\end{array}$ & $\begin{array}{c}8.3 \\
15(8.1-8.4) \\
0.11\end{array}$ & $\begin{array}{c}8.1 \\
6(7.9-8.3) \\
0.17\end{array}$ \\
\hline Rostral breadth & $\begin{array}{c}7.5 \\
16(7.2-7.7) \\
0.18\end{array}$ & $\begin{array}{c}7.4 \\
6(7.3-7.5) \\
0.08\end{array}$ \\
\hline $\begin{array}{l}\text { Postorbital } \\
\text { constriction }\end{array}$ & $\begin{array}{c}4.0 \\
16(3.8-4.2) \\
0.10\end{array}$ & $\begin{array}{c}4.0 \\
6(3.9-4.1) \\
0.10\end{array}$ \\
\hline $\begin{array}{l}\text { Zygomatic } \\
\text { breadth }\end{array}$ & $\begin{array}{c}9.9 \\
16(9.7-10.2) \\
0.17\end{array}$ & $\begin{array}{c}9.9 \\
5(9.7-10.1) \\
0.15\end{array}$ \\
\hline $\begin{array}{l}\text { Maxillary } \\
\text { toothrow }\end{array}$ & $\begin{array}{c}7.1 \\
15(7.1-7.2) \\
0.05\end{array}$ & $\begin{array}{c}7.2 \\
6(7.1-7.2) \\
0.05\end{array}$ \\
\hline $\begin{array}{l}\text { Breadth across } \\
\text { upper molars }\end{array}$ & $\begin{array}{c}6.7 \\
16(6.5-7.0) \\
0.12\end{array}$ & $\begin{array}{c}6.7 \\
6(6.7-6.9) \\
0.08\end{array}$ \\
\hline
\end{tabular}


Some measurements of the new specimens (Table 1) confirm the observations of Smith (1972) with respect to the progresive decrease of size, at least from the northern most localities in Middle America down to the southern region of Venezuela.

\section{Tonatia carrikeri (J.A. Allen)}

Specimens examined (1). T.F. Amazonas : margin of Río Baria, Parque Nacional Serrania La Neblina, $140 \mathrm{~m}\left(0^{\circ} 55^{\prime} \mathrm{N}, 66^{\circ} 6^{\prime} \mathrm{W}\right), 1$ \& (EBRG).

This bat had only been recorded in Venezuela from nine specimens (McCarthy et al. 1983): seven from Rio Mocho (Bolivar), which correspond to the type series (Allen 1910), and two from central and northern T.F. Amazonas (Handley 1976). The specimen reported here extends the known range of this bat to the meridional extreme of the country. Some measurements are : forearm, 44.7 ; total length of the skull, 23.5 ; postorbital constriction, 3.5 ; breadth of braincase, 9.4 ; zygomatic breadth, 10.5 ; maxillary toothrow, 7.9 ; breadth across upper molars, 6.9. Non identifiable insect remains were found in its stomach contents.

\section{Eptesicus diminutus Osgood}

Specimens examined (1). BARINAS : Finca El Oasis, $42 \mathrm{~km}$ E Barinas, $100 \mathrm{~m}\left(8^{\circ} 38^{\prime} \mathrm{N}\right.$, $\left.69^{\circ} 48^{\prime} \mathrm{W}\right), 1$ o $(\mathrm{EBRG})$.

Previous records of this species from northern South America have been reported by Handley (1976) and Ibañez (1981), based on specimens collected in two localities from the llanos region of Venezuela (Guarico and Apure). The new specimen extends the known distribution of this bat in Venezuela westwards, near the foothill of the Andean Cordillera. Some measurements are : forearm, 35.7 ; total length of the skull, 15.1 ; postorbital constriction, 3.7 ; breadth of braincase, 7.3 ; maxillary toothrow, 5.3 ; breadth across upper molars, 6.1.

\section{Nyctinomops macrotis (Gray)}

Specimens examined (3). MERIDA : city of Mérida, $1650 \mathrm{~m}\left(8^{\circ} 35^{\prime} \mathrm{N}, 71^{\circ} 8^{\prime} \mathrm{W}\right), 1$ (CVUlA). T.F. Amazonas : Parque Nacional Serrania La Neblina, $2.8 \mathrm{~km}$ NE Pico Phelps, $2100 \mathrm{~m}\left(0^{\circ} 49^{\prime} \mathrm{N}, 65^{\circ} 59^{\prime} \mathrm{W}\right), 1$ \& (EBRG). Caño Negro, Cerro Marahuaca, Parque Nacional Duida-Marahuaca, $1200 \mathrm{~m}\left(3^{\circ} 38^{\prime} \mathrm{N}, 65^{\circ} 28^{\prime} \mathrm{W}\right), 1$ \% (MBUCV).

The name $N$. macrotis was previously used by Ojasti and Linares (1971), and Ochoa and Bisbal (1982), for three specimens collected in Aragua. The taxonomy of this material was later revised by Ochoa (1984), corresponding to $N$. aurispinosus. The specimens reported here represent the first record of $N$. macrotis in Venezuela. Some measurements of the female from La Neblina and the female from Marahuaca, are respectively : forearm, 61.3, 58.8; total length of the skull, $23.0,22.4$; rostral breadth, 5.7, ..- ; postorbital constriction, $4.0,4.0$; breadth of braincase, 10.0, 9.8 ; zygomatic breadth, 12.5, 12.5 ; mastoid breadth, 11.5, --- ; palatal length, 9.6, 8.7 ; maxillary toothrow, 8.6, 8.4 ; breadth across upper molars, 8.6, 8.5. The stomach content of the female from La Neblina showed Coleoptera, Hemiptera and other non identifiable insect remains. 


\section{Eumops hansae Sanborn}

Specimens examined (2). Aragua : Portachuelo, Rancho Grande, Parque Nacional Henri Pittier, $1100 \mathrm{~m}\left(10^{\circ} 22^{\prime} \mathrm{N}, 67^{\circ} 41^{\prime} \mathrm{W}\right), 1$ \& (EBRG). Barinas : Reserva Forestal de Ticoporo, Unidad II, $100 \mathrm{~m}\left(8^{\circ} 10^{\prime} \mathrm{N}, 70^{\circ} 40^{\prime} \mathrm{W}\right), 1 \sigma^{\circ}$ (EBRG).

Handley (1976) reported the first record of this bat in Venezuela based on two specimens collected in Bolivar and T.F. Amazonas, to which he assigned the name E. amazonicus. Subsequently, it had been recorded only by Eisenberg et al. (1979), when they included it in a list of mammals from the llanos region of Guarico. The new specimens extend its known distribution in Venezuela north and westwards, and represent the first record from the Cordillera de la Costa, at an altitude of $1100 \mathrm{~m}$ in a premontane very humid forest life zone, according to Ewel et al. (1976). Some measurements of the female from Aragua and the male from Barinas, are respectively : forearm, 36.2, 39.1; total length of the skull, 17.0, 19.4 ; zygomatic breadth, ---, 11.3 ; postorbital constriction, 3.7, 4.1 ; breadth of braincase, $8.5,8.7$; rostral breadth, $5.4,6.4$; palatal breadth, 6.3, 7.6 ; mastoid breadth, 9.6, 10.2 ; breadth across upper canines, 3.9, 4.6 ; maxillary toothrow, $6.5,7.1$; breadth across upper molars, 7.7, 7.9. In these specimens we observed an evident sexual dimorphism, exhibited principally in the size and the development of sagittal and lamboidal crests.

\section{Oryzomys yunganus Thomas}

Specimens examined (3). T.F. Amazonas, Parque Nacional Duida-Marahuaca : summit of Cerro Duida, $1100 \mathrm{~m}\left(3^{\circ} 12^{\prime} \mathrm{N}, 65^{\circ} 36^{\prime} \mathrm{W}\right) 1 \sigma^{\circ}$ (MBUCV). Summit of Cerro Marahuaca $\left(3^{\circ} 38^{\prime} \mathrm{N}, 65^{\circ} 28^{\prime} \mathrm{W}\right), 20^{\circ} 0^{\circ}$ (MIZAUCV).

The specimens reported here (two adults and one subadult) correspond with the characters cited by Musser and Williams (1985) for this species. Its distribution had been restrinted to the east side of the Andean Cordillera, from Peru to Bolivia (Honacki et al. 1982); the venezuelan specimens would represent the first record for the Guyana Region, where probably the species inhabits forested areas higher than $1000 \mathrm{~m}$ above sea level. Some measurements of the male from Cerro Duida, followed by those of one male from Cerro Marahuaca, are respectively : total length, 228,245 ; tail, 117,110 ; hind foot, 31,28 ; ear, 19,16 ; total length of the skull, 30.8, --- ; condylobasal length, 28.5, 29.1 ; basal length, 26.5 , --- ; palatal length, 7.3, 7.0 ; interorbital constriction, 5.4, 5.2 ; zygomatic breadth, 15.6, 16.6 ; breadth of braincase, $12.8,13.4$; diastema, $8.1,8.1$; height of rostrum, 7.5, 8.2 ; alveolar length $\mathrm{m}^{1}-\mathrm{m}^{3}, 4.9,4.9$; length of mandibule, $17.6,18.0$; alveolar length $\mathrm{m}_{1}-\mathrm{m}_{3}, 5.1,5.3$

\section{Ichthyomys pittieri Handley and Mondolfi}

Specimens examined (4). Aragua, Parque Nacional Henri Pittier, $1100 \mathrm{~m}\left(10^{\circ} 22^{\prime} \mathrm{N}\right.$, $\left.67^{\circ} 41^{\prime} \mathrm{W}\right)$ : Quebrada La Guacamaya, $10^{\circ}$ (EBRG) ; Rancho Grande, 2 ९ (EBRG) and $1 \%$ (CVULA).

The only previous records of this rarely collected rodent are three specimens, all from the Cordillera de la Costa in Venezuela (Handley and Mondolfi 1963 ; Voss et al. 1982) : two from Parque Nacional Henri Pittier (Aragua), including 
the holotype, and one from Parque Nacional El Avila (Distrito Federal). Some measurements of one male cited here from Rancho Grande are : total length, 219 ; tail, 105 ; hind foot, 26 ; ear, 10 ; condylobasal length, 27.0 ; basal length, 24.6 ; palatal length, 13.8 ; interorbital constriction, 5.0 ; zygomatic breadth, 13.4 ; breadth of braincase, 11.9 ; diastema, 7.3 ; alveolar length $\mathrm{m}^{1}-\mathrm{m}^{3}, 3.4$; length of mandibule, 15.1; alveolar length $\mathrm{m}_{1}-\mathrm{m}_{3}, 3.3$.

\section{ACKNOWLEDGEMENTS}

The following persons allowed us to study the specimens deposited in the collections under their care : G. Cordero (MBUCV), J. Pefaur and P. Soriano (CVULA), and A. Fernandez (MIZAUCV); M. de Ayarzagüena and J. Gomez Nuñez, assisted us in the transcription of the manuscript ; the Fundación para el Desarrollo de las Ciencias Físicas, Matemáticas y Naturales supported the research of J. Ochoa G. in the Parque Nacional Serrania La Neblina. We Wish to thank all for their collaboration.

\section{BIBLIOGRAPHY}

Allen, J.A., 1910. - Mammals from the Caura District of Venezuela, with description of a new species of Chrotopterus. Bull. Amer. Mus. Nat. Hist., 28 : 145-149.

EISENBERG, J.F., M.A. O'ConNell and P.V. August, 1979. - Density, productivity, and distribution of mammals in two venezuelan habitats. Pp. 187-207, in : Vertebrate ecology in the northern neotropics (J.F. EISENBERG, ed.). Smithsonian Inst. Press, Washington, D.C. $271 \mathrm{pp}$.

Ewel, J.J., A. MAdriz and J.A. Tosi, 1976. - Zonas de vida de Venezuela. 2nd ed. Ministerio de Agricultura y Cría, Caracas, 265 pp.

HANDLEY, C.O., Jr., 1976. - Mammals of the Smithsonian Venezuelan Project. Brigham Young Univ. Sci. Bull., Biol. Ser., 20 (5) : 1-89.

Handley, C.O., Jr., and E. Mondolfi, 1963. - A new species of fish-eating rat, Ichthyomys, from Venezuela (Rodentia, Cricetidae). Acta Biol. Venezuelica, 3: $417-419$.

HONACKI, J.H., K.E. KINMAN and J.W. KOEPPL, 1982. - Mammals species of the world. Allen Press Inc. and Assoc. Syst. Collec. Kansas, U.S.A. 694 pp.

IbaÑEz, U., C.J., 1981. - Biología y ecología de los murciélagos del hato "El Frio ", Apure, Venezuela. Doñana, Acta Vert., 8-4 (spec. num.) : 1-271.

McCarthy, T.J., A. Cadena, G. and T.O. Lemke, 1983. - Comments on the first Tonatia carrikeri (Chiroptera : Phyllostomatidae) from Colombia. Lozania, $40: 1-6$.

MUSSER, G., and M. Williams, 1985. - Systematic studies of oryzomyine rodents (Muridae) : definitions of Oryzomys villosus and Oryzomys talamancae. Amer. Mus. Nat. Hist., 2810 : 1-22.

OснOA, G., J., 1984. - Presencia de Nyctinomops aurispinosa en Venezuela (Chiroptera : Molossidae). Acta Cient. Venezolana, $35: 147-150$.

OCHOA, G., J., and F. Bisbal, 1982. - Mamíferos en la colección de la Estación Biológica de Rancho Grande, Venezuela. Minist. Ambient. Rec. Nat. Renov., Ser. Publ. Datos, DGSIIA/PD/03. $54 \mathrm{pp}$.

OJASTI, J., and O. LiNARES, 1971. - Adiciones a la fauna de murciélagos de Venezuela, con notas sobre las especies del género Diclidurus (Chiroptera). Acta Biol. Venezuelica, $7:$ 421-441. 
REIG, O., 1977. - A proposed unified nomenclature for the enamelled components of the molars teeth of the Cricetidae (Rodentia). J. Zool., London, 181 : 227-241.

SMITH, J.D., 1972. - Systematics of the chiropteran family Mormoopidae. Misc. Publ. Mus. Nat. Hist., Univ. Kansas, $56: 1-132$.

- 1977. - On the nomenclatural status of Chilonycteris gymnonotus Natterer, 1843. J. Mamm., 58 : 245-246.

Voss, R.S., J.L. SILVA and J.A. VALDES, 1982. - Feeding behavior and diets of neotropical water rats, genus Ichthyomys Thomas, 1893. Z. Säugetierkunde, $47: 364-369$. 